\title{
A rare case of parietal bone hemangioma
}

\author{
Arif Hussain Sarmast, Yaavar Shafi ${ }^{1}$, Altaf Rehman Kirmani, Abdul Rashid Bhat \\ Departments of Neurosurgery and ${ }^{1}$ Pathology, Sher I Kashmir Institute of Medical Sciences SGR, Jammu and Kashmir, India
}

A 40-year-old female was presented with the painless swelling-paintal area, progressively increasing in six, for the last 2 years. The patient complained of local tenderness. Antero-posterior and lateral views of plain X-ray skull revealed classical honeycomb appearance lesion [Figure 1]. A computed tomography (CT) scan of the head with bone window images showed the hypodense lesions with sharp, thickened, sclerotic margins [Figure 2]. En bloc excision of the tumor bearing bone and wide curettage was done until healthy margins of the bone were seen all around. Underneath durameter was not involved and was healthy. Curetted vascular tumor along with the bone pieces was sent for histopathological examination, which was also subsequently reported as hemangioma.

Primary intraosseous hemangiomas are benign slow growing neoplasms. More than $50 \%$ occur in the vertebrae and skull. ${ }^{[1]}$ They are rare tumors in the calvarium and represent $2 \%$ of osseous calvarial lesions and $0.2 \%$ of all bone neoplasms. ${ }^{[2]}$ The parietal and frontal bones are the most common locations, but may occur in any skull bone. In very rare instances multifocal hemangiomas may occur. They are found more frequently in females ${ }^{[1,2]}$ Calvarial haemangiomas are benign, malformed vascular lesions, are usually asymptomatic and are usually, discovered incidentally on imaging or post-mortem examination. They are mostly encountered in the middle-aged persons, generally occurs more commonly in females than

Address for correspondence:

Dr. Arif Hussain Sarmast, Dalipora, Kawadara, Srinagar,

Jammu and Kashmir, India.

E-mail: arifhsarmast@gmail.com

\begin{tabular}{|l|l|}
\hline \multicolumn{2}{|c|}{ Access this article online } \\
\hline Quick Response Code: & Website: \\
\hline & www.ruralneuropractice.com \\
\cline { 2 - 2 } & \\
\hline
\end{tabular}

males with a ratio of 3:2. There is no documental racial variation in the frequency of hemangiomas of skull, worldwide. ${ }^{[1-3]}$

The differential diagnosis of a solitary circumscribed expansile intradiploic cranial lesion includes an osteoma, aneurysmal bone cyst, giant cell tumor, fibrous dysplasia, Langerhans' cell histiocytosis, sarcoma, meningioma, metastatic disease, Paget's disease, lymphoma, and dermoid tumor. ${ }^{[1]}$ According to the predominant type of vascular channel, four histological variants of hemangiomas are known; cavernous, capillary, arteriovenous, and venous. Bone hemangiomas are predominantly of the cavernous and capillary varieties. Cavernous hemangiomas most frequently occur in the skull whereas capillary hemangiomas predominate in the vertebral column, overall cavernous ones are commonly seen. ${ }^{[4]}$

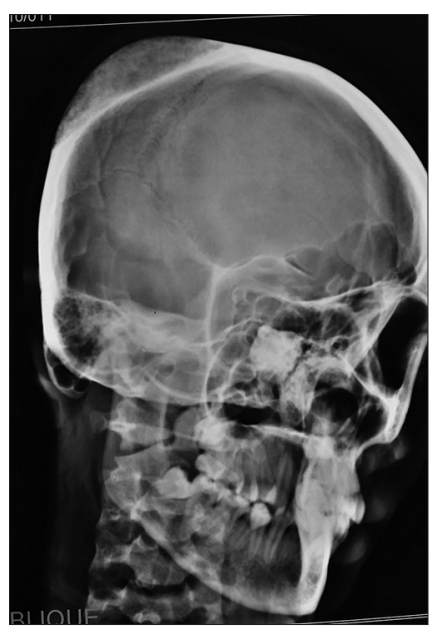

Figure 1: Lateral views of plain X-ray skull revealing classical honeycomb appearance lesion

This is an open access article distributed under the terms of the Creative Commons Attribution-NonCommercial-ShareAlike 3.0 License, which allows others to remix, tweak, and build upon the work non-commercially, as long as the author is credited and the new creations are licensed under the identical terms.

For reprints contact: reprints@medknow.com

How to cite this article: Sarmast AH, Shafi Y, Kirmani AR, Bhat AR. A rare case of parietal bone hemangioma. J Neurosci Rural Pract 2016;7:456-7. 


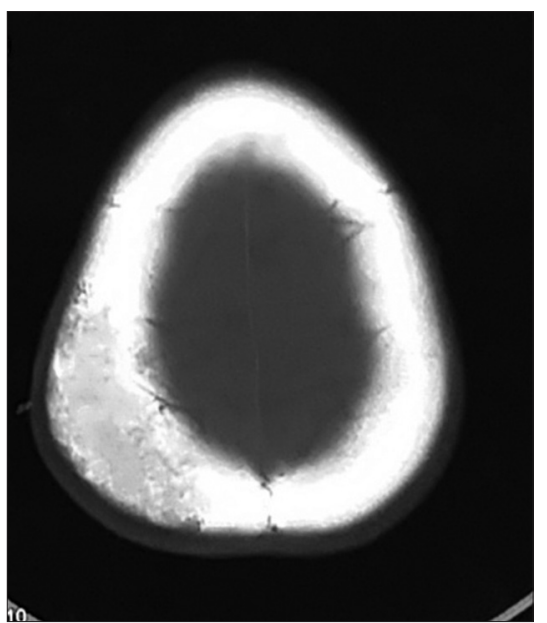

Figure 2: Noncontrast computed tomography head (axial view, bone window) image showing the hypodense lesions with sharp, thickened, and sclerotic margins

Evaluation of cranial vault hemangioma starts with a plain radiograph, followed by CT head and magnetic resonance imaging brain. Digital subtraction angiography and skeletal scintigraphy may also be done but not that frequently. Treatment is not always necessary and indications include: Mass effects, hemorrhage control, and esthetic improvement. Whenever indicated total surgical removal is the recommended treatment and is determinant of a definitive diagnosis Radiotherapy is advisable in situations where excision is not feasible. ${ }^{[5]}$

\section{Financial support and sponsorship}

Nil.

\section{Conflicts of interest}

There are no conflicts of interest.

\section{References}

1. Suzuki Y, Ikeda H, Matsumoto K. Neuroradiological features of intraosseous cavernous hemangioma - Case report. Neurol Med Chir (Tokyo) 2001;41:279-82.

2. Peterson DL, Murk SE, Story JL. Multifocal cavernous hemangioma of the skull: Report of a case and review of the literature. Neurosurgery 1992;30:778-81.

3. Koulouris G, Rao P. Multiple congenital cranial hemangiomas. Skeletal Radiol 2005;34:485-9.

4. Politi M, Romeike BF, Papanagiotou P, Nabhan A, Struffert T, Feiden W, et al. Intraosseous hemangioma of the skull with dural tail sign: Radiologic features with pathologic correlation. AJNR Am J Neuroradiol 2005;26:2049-52.

5. Reis BL, Carvalho GT, Sousa AA, Freitas WB, Brandão RA. Primary hemangioma of the skull. Arq Neuropsiquiatr 2008;66:569-71. 